\title{
波面制御と原子波ホログラフィー
}

\author{
藤田 淳一 \\ 筑波大学物理工学系 (テ305-8573 茨城県つくば市天王台1-1-1)
}

\section{Wave Front Control and Atomic Wave Holography}

\author{
Jun-ichi FUJITA \\ Institute of Applied Physics, University of Tsukuba, 1-1-1, Tennodai, Tsukuba, Ibaraki 305-8573
}

(Received December 24, 2003)

\begin{abstract}
We describe various techniques to manipulate laser-cooled Ne atoms interferometrically by using a silicon nitride film with holes and electrode deposition. Laser-cooled $\mathrm{Ne}$ atoms pass through a computer-generated through-hole binary hologram and generate an atomic image on a substrate. The hologram can be designed to provide a spherical phase correction, and the reconstructed pattern is focused on the substrate at a finite distance from the hologram. Such holographic manipulation can be extended to gray-scaled reconstruction that is used to deposit relief-like 3D atomic patterns on surfaces. In addition, an atom interacts with electric, magnetic, and optical fields. This provides the holographic atomic-wave manipulation to perform functions that are difficult for a light wave. The Stark shift induced by an external electric field is used to switch and to modify atomic patterns in real time. We also introduce an reflecting type atom holography by using quantum reflection.
\end{abstract}

Key Words: Laser cooling, de Broglie wave, Hologram, Quantum reflection

1. はじめに

室温における原子のド・ブロイ波長は 10 ピコメートル 程度と極めて短かい。 また中性原子と外場(電場, 磁場) と の相互作用は極めて弱いために，外場を用いて中性原子 を操作する事は容易ではない. しかしながら，1980年代 以降のレーザー冷却技術の発達1,2) により，この状況は一 変しつつある. 原子をレーザー冷却し, ミリケルビンの 領域に達すると物質が本来持っている波(ド・ブロイ波) と しての性質が顕著に現れる。この原子の波動性を利用 し, 光学干渉と同様に原子波干渉を用いて原子波操作が 可能となった。これまでに，スリットを通過する $\mathrm{Na}$ 原子 の干渉3)や，レーザー定在波による原子操作 ${ }^{4)}$ が報告され ている．本稿では，原子波光学応用の観点から，ホログ ラムを用いた原子波操作, 電界による原子波位相制御, また近年の量子反射ホログラフィーに至る原子波ホログ ラフィー技術について紹介する。

\section{2. 原子波ホログラフィーの原理}

ホログラフィーとは一定の波面をホログラムと呼ばれ る乾板を透過，または反射させることにより任意の波面 に再構成する手法である。ホログラムの合成方法とし て，例えば物体からの光に参照光を照射し，位相情報を
振幅情報に変換して写真乾板に記録する昔ながらの方法 と, 計算によって透過率を求め, それを適当なフィルム 上に実現する計算機ホログラムの合成方法がある，原子 波ホログラフィーの場合は，光のように半透膜を透過さ せる事ができないので, 透過(1) か不透過 (0)の2值で表現 する計算機ホログラムを用い, 原子波を透過・干渉させ る事で原子像の再生を行う。ホログラムによって作り出 される振幅透過率には多少の制約がつくものの, ホログ ラムは任意の波面を作り出せるという意味で波面光学素 子として極めて汎用性が高い. また, ホログラム中に記 録された情報は分散化されノイズに強い.すなわち，ホ ログラム上に傷，欠損があっても再生できる事でも大き な特徵である。

原子波ホログラフィーの原理は極めて単純である(しか し，実験に用いるレーザー冷却技術と超微細加工技術は 過去の膨大な研究蓄積の上に成り立つものであり別途参 照していただきたい). 原子の速度がゼロに近い点原子源 の鉛直下方にホログラムを置き, 自由落下してくる原子 (波)を干渉させ，さらにその下に置かれたスクリーン上で 再生原子像を観測する，という構成である，以下，我々 がたどってきた時間軸に沿って，原子波ホログラフィー の技術的発展を紹介したい. 


\section{Ne原子を用いた原子波ホログラフィー再生系}

原子波をホログラム再生用光源として用いるために は, 波長の揃った点光源の原子波を得る必要がある。こ のためには, 少なくとも数十マイクロケルビン程度の極 低温に3次元冷却された原子波が必要となる。このような 極低温に原子を冷却する方法として，レーザートラップ による冷却方法が用いられる ${ }^{1,2)}$. Fig. 1にNeのレーザー 冷却装置の概要を示す. 装置は大まかに, グロー放電に より励起状態の $\mathrm{Ne}$ 原子を生成する放電部分, 原子ソース の輝度を上げ，かつ，基底状態原子を除去するための偏 向器 (Deflector), 第一段の冷却領域 (Zeeman Slower), 第 二段の冷却領域 (Magneto-Optic Trap) と実験領域に分かれ る。 $\mathrm{Ne}$ 原子のレーザートラップでは, $1 \mathrm{~s}_{5}(\mathrm{~J}=2)$ と $2 \mathrm{p}_{9}(\mathrm{~J}$ $=3)$ の間の遷移 $(640.2 \mathrm{~nm})$ を利用する。 この最低励起状態 は寿命が長い準安定状態である。レーザー冷却系最終段 の磁気光学トラップで, $\mathrm{Ne}$ 原子は約 $50 \mu \mathrm{K}$ 程度に冷却さ れ, 直径約 $0.3 \mathrm{~mm}$ 程度の $\mathrm{Ne}$ 原子クラウドが形成される。 この Neクラウドに対して $598 \mathrm{~nm}$ のレーザを照射し, 最終 的に $1 \mathrm{~s}_{3}(\mathrm{~J}=0)$ の準安定状態に遷移した原子がトラップか ら開放され，自由落下の途中でホログラムを通過し干渉 する。

実際の実験では，例えばFig. 1に示す様に原子のトラッ プ位置から約 $40 \mathrm{~cm}$ 程度原子を自由落下させ, この位置に $\mathrm{SiN}$ メンブレン上に形成されたホログラム(Fig. 2)を置く. このホログラム位置で原子は $280 \mathrm{~cm} / \mathrm{sec}$ の速度を持ち, $\mathrm{Ne}$ 原子のド・ブロイ波長 $(\lambda=h / m v)$ は7.1 nmである. 原子波 の速度分散は3 $310^{-3}$ 程度で, 原子波としては非常に良好 である。原子再生像の検出はホログラムからさらに下方 に設置されたMCP(マイクロ・チャネル・プレート)で検 出する.

\section{4. 様々な原子波ホログラムの再生}

\subsection{Fraunhofer型のホログラム再生}

まず再生したい像 $G(X, Y)$ を用意する。用意した像は英 文字”F”であり, 光学系ではその非対称性が好都合なため に良く用いられるが，同時に筆者らのイニシャルでもあ る. ホログラムの振幅透過関数 $T(x, y)$ はスクリーン上に 再生される像 $G(X, Y)$ のフーリ工変換である. 従って $T$

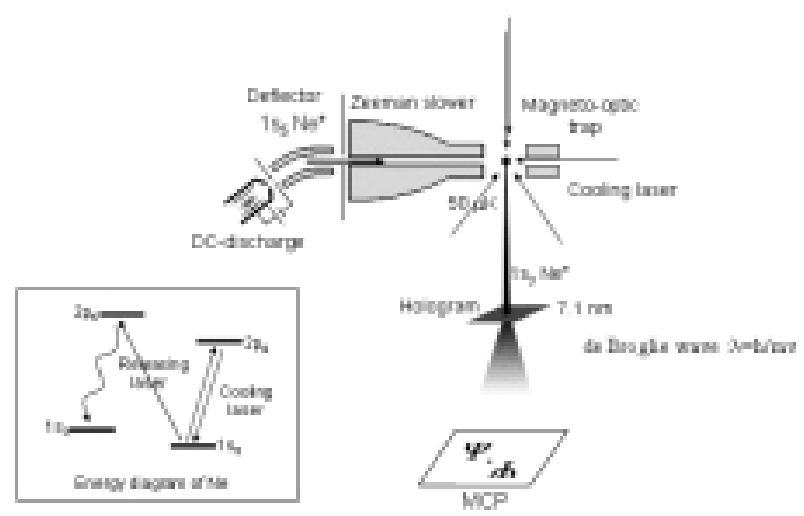

Fig. 1 Optics for atom holography.

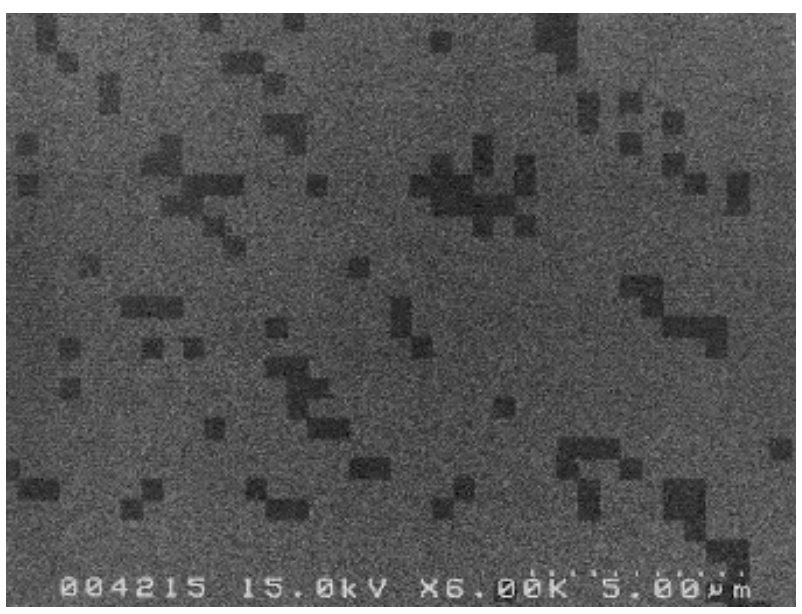

Fig. 2 Hologram pattern fabricated on $\mathrm{SiN}$ membrene.

$(x, y)$ は $G(X, Y)$ を逆フーリエ変換することによって計算 され，これは一般に複素数值をとる。回折の計算は最も 簡単に原子源 (点原子源) とホログラム, ホログラムとスク リーンとの間の距離が十分大きいとしたFraunhofer回折近 似を用いる。ホログラムは薄膜に穴を開けただけのもの なので透過率は 0 または 1 の実数值しかとれない.さらに ホログラムに開ける穴の形・大きさは固定されており， 穴を開ける位置も等間隔に離散化されている，いわゆる Lohmann型ホログラム5)である。この設計手法では，開口 または閉口一つ一つをサブセルと呼び， $4 \times 4$ のサブセル を便宜上ひとまとめにしてセルと呼ぶ。このセル単位で 対応する位置の透過関数 $T(x, y)$ を表現する．ホログラム の縦横方向に $x-y$ 軸をとり，例えば $x$ 方向で位相を表現す る. $x$ 方向では1つのセルごとに位相 $2 \pi$ を表現する事にな るから，1つサブセルを進むごとに位相が $\pi / 4$ 進む様に定義 する事ができる，するとy軸方向に並べて開けるサブセル の数で透過する原子波の振幅を, $x$ 軸方向に穴を開ける位 置をずらすことによって位相を調整出来るので, セル単 位で $T(x, y)$ を表現することができる。

文字"F"を再生するように設計されたホログラムは，サ ブセルの形が $300 \mathrm{~nm}$ 角の正方形，サブセル間隔も $300 \mathrm{~nm}$ で, $128 \times 128$ のセル $(512 \times 512$ のサブセル)から構成され ている。このようなホログラムを用いて，10時間積算し た結果をFig. 3に示す. 原子線のビーム径はホログラム直 下に設置された $0.2 \mathrm{~mm}$ のアパーチャで絞られている. 再 生像の分解能はアパーチャをMCPスクリーンに投影した 大きさ $0.3 \mathrm{~mm}$ 程度となる. MCP(マイクロ・チャンネル プレート)に到達したNe原子は63237個である。明確な”F” パターンとその共役像, 及びそれらの高次再生像が見え

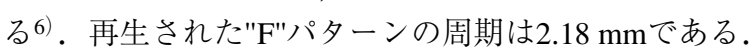

\section{2 球面波補正ホログラフィー}

Fraunhofer型ホログラムではビームアパーチャーがその 分解能を決定してしまうことになる。これを改善するに は, 原子経路に依存した位相 $\phi$ 考慮したFresnel回折を計 算すればよい，点光源からの原子波がホログラムで回折 し，スクリーン面に到達したときの強度分布 $G(X, Y)$ はホ ログラム面での透過関数を $T(x, y)$ とし, 古典的な原子の 


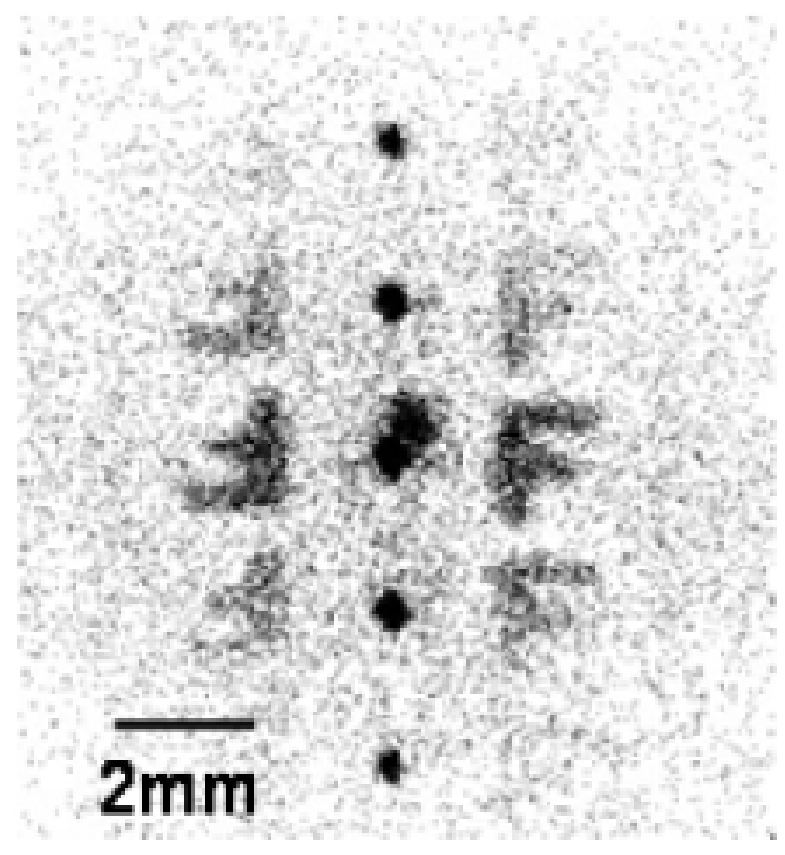

Fig. 3 Reconstruction of "F" pattern.

軌跡に沿った位相を

$$
\phi(X, Y, x, y)=\int_{p a t h} \frac{P}{\hbar} d l
$$

として,

$$
G(X, Y)=\int T(x, y) \exp (-i \phi) d x d y
$$

で表される， $\phi は X, Y, x, y$ の関数で，光源とホログラム 間の距離および，ホログラムとスクリーン間距離がホロ グラムサイズに比べて十分に大きい場合には2次の関数と して扱うことができる。この場合， $T(x, y)$ は $G(X, Y)$ の フーリエ変換に球面波位相を乗じた形で解析的に取り扱 うことが可能である. 以下のホログラムでは, フーリエ 変換によって得られた複素透過振幅をあるしきい值以上 の正実数部分を透過(開口セル)としてホログラムを形成し ている， $\phi$ の展開として $X, Y, x, y$ の次までの線形結合 を取ると(2)式は解析的に解く事ができて，FFTアルゴリ ズムを活かしたまま, 球面波位相項を処理する事で数值 的に透過関数を求める事ができる7). これはホログラムの 前後にコリメータと集束レンズを置くことと等価であ 万.

Fresnel回折ホログラム7) として"atom $\mathrm{Ne} \Psi^{\prime \prime}$ パターンを用 いた結果をFig. 4に示す。 "atom Ne $\Psi^{\prime \prime の ホ ロ ク ゙ ラ ム て ゙ は ホ ~}$ ログラムを構成する単位セルサイズを $180 \mathrm{~nm}$ で形成して いる．再生像は上下に点対称でパターンが形成されてい るが，上のパターンは明瞭で下のパターンはデフォーカ スとなっている。これは，レンズ効果が正常に機能して いることを示している．すなわち，レンズ効果が機能す ると, その共役像のフォーカス位置がずれるためにデ フォーカスとなる。このパターンサイズはatomの左端か

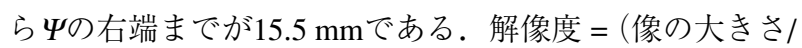

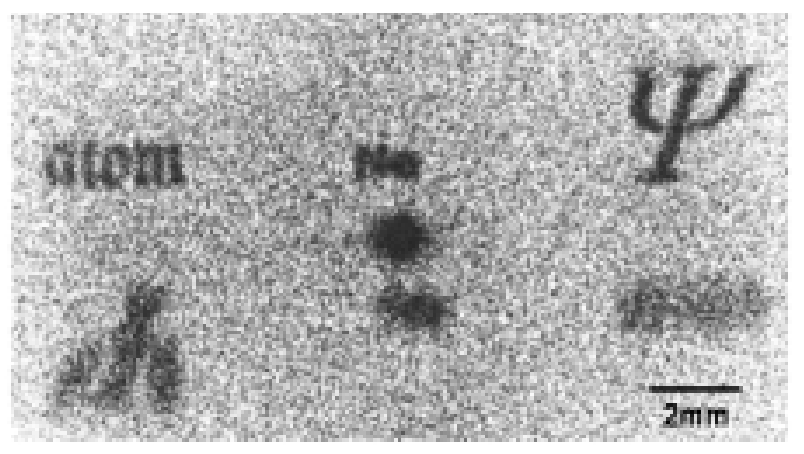

Fig. 4 Reconstruction with spherical wave correction.

分解能)として150が得られている.

\section{3 グレー階調ホログラフィー}

これまで紹介した原子波ホログラフィーでは, 再生さ れる像は白黒の2值パターンであったが，再生像に対して 輝度変調のかかったグレーレベル像の再生，いわゆる写 真画像の再生が可能である。すなわち，画像輝度の明暗 に対応して，原子堆積量が変化するわけであり，原子波 ソースに金属等の原子を用いれば基板表面に3次元構造を 堆積できることになる。グレー階調再生に必要とされる ホログラムは，従来の白黒再生ホログラムと原理的には 何ら変わったものではなく，単純にホログラムの元絵を 白黒2值パターンからグレー階調の絵に変更するだけでよ い。ただし，当然ながらホログラムの情報量が増えるわ けで，これに対応した大容量のホログラムと，増えた情 報を再生するために，さらに強力な原子波源が必要とな る。グレー階調ホログラフィーでは再生効率を上げ大量 の原子を透過・回折させるためにマルチホログラムを利 用している。単純に同じホログラムを並べただけでは， 並べた枚数分の再生像が重なって出てきてしまうが, 並 べる位置に応じた位相を付加することで, すべての再生 像が同じ位置に重なるように調整する。

このようなグレー階調ホログラフィー8)の例としてFig. 4にJuliano像のシミュレーションと再生像を示す. 元絵は Juliano de Medici像であり，8階調のグレーレベルで構成さ れている，基本ホログラムは $1024 \times 1024$ ピクセルで構成 され, これが縦横に4枚ずつ, 計16枚のマルチホログラム となっている．この場合再生像の分解能は $1024 \times 1024$ の 基本ホログラムの大きさで決まり, 約 $12 \mu \mathrm{m}$ 程度の分解能 が期待される。ホログラムの開口率は $25 \%$ とし, 短時間 の装置運転で最大限の再生像の輝度が得られる設計であ

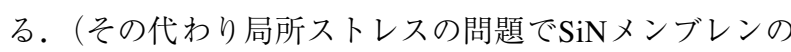
加工は予想以上に困難を極めた)．Juliano像のホログラム では，ホログラムのピッチが $200 \mathrm{~nm}$ ，ホログラムの総サ イズが4096×4096ピクセル，穴の総個数412万個となって いる．像の再生には2時間を要し，計数した原子の総数は 64万7873個, 実像と虚像との距離は約 $5 \mathrm{~mm}$ である. 良好 なグレー階調が再現されている事がわかる.

4.4 電界変調ホログラフィー

従来の原子波ホログラムでは，一番最初の"F"パターン 

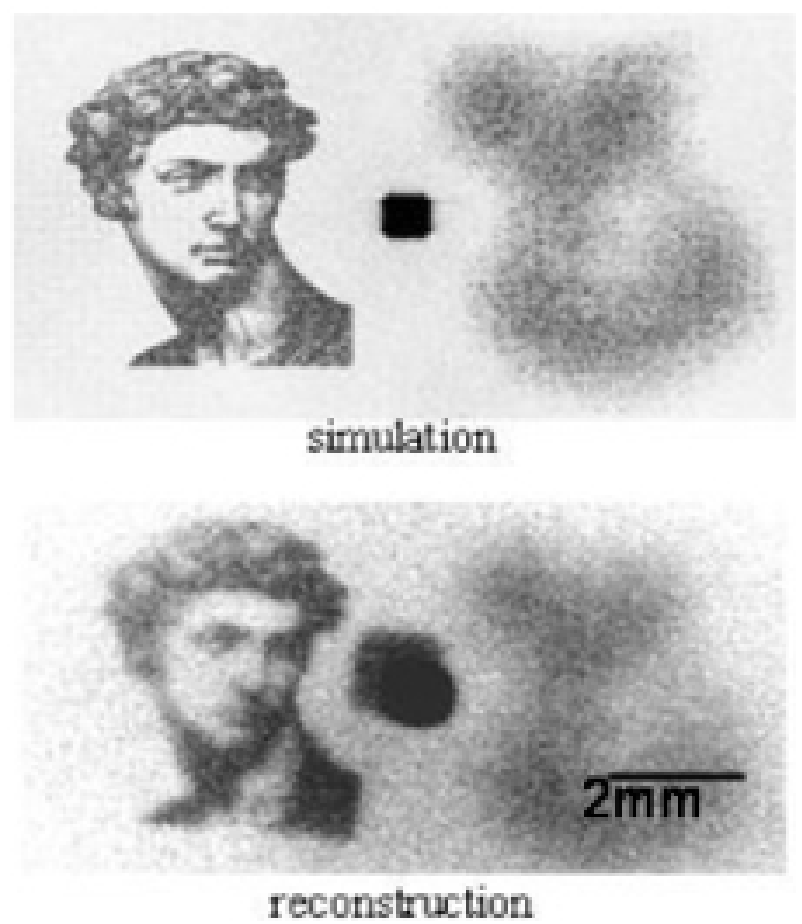

Fig. 5 Simulation and reconstruction of gray image "Juliano".

を除き(これは振幅・位相ホログラムである), すべてが振 幅ホログラムであった。つまり，ホログラム面に記録さ れているのは原子波の透過振幅情報である。ホログラム の情報は本来複素数であるから，位相と振幅で表される が, 振幅ホログラムでは位相角が $\pi / 2$ から $3 \pi / 2$ 間の負の振 幅を与える情報を無視して2值化してきた。このために， ゼロ次光が出現し, 共役像が出現した. しかし, 電場に よる原子波の位相制御機能をホログラムに付加し, $\pi$ 位相 の透過振幅を表現する事で, ゼロ次光の消去, パターン の消去，パターンの入れ替えが可能となる9).

原子波の位相制御には2次のStark効果を利用する。原子 (波)が電場中を通過するとStark効果による内部エネル ギーレベルがシフトし, 原子波の位相変化を引き起こ す. 原子が電場 $E$ に対して感じるStarkポテンシャルUは原 子の分極率を $\alpha$ とすれば

$$
U=-\alpha E^{2} / 2
$$

と書ける.この原子が速度 $て て ゙$ 通過するときの位相シフト は,

$$
\phi=\frac{1}{\hbar} \int U d t \approx-\frac{\alpha}{2 v \hbar} \int E^{2} d z
$$

となる。事前の実験で， $2.6 \mathrm{~m} / \mathrm{s}$ の速度を持つ原子に対して $10^{4} \mathrm{~V} / \mathrm{cm}$ の電場を与えると位相シフト $\pi$ 得られる事が分 かっている.

ここでは，電界変調によるパターンの入れ替えを紹介 する. 用いる電極構造はFig. 6に示すようなA, Bの電位端 子に接続された 2 組の櫛形電極を組み合わせたものであ り，2つの電極にはさまれた空間でゼ口位相と $\pi$ 位相を表 現する。つまり同電位に挟まれた空間はゼロ位相であ

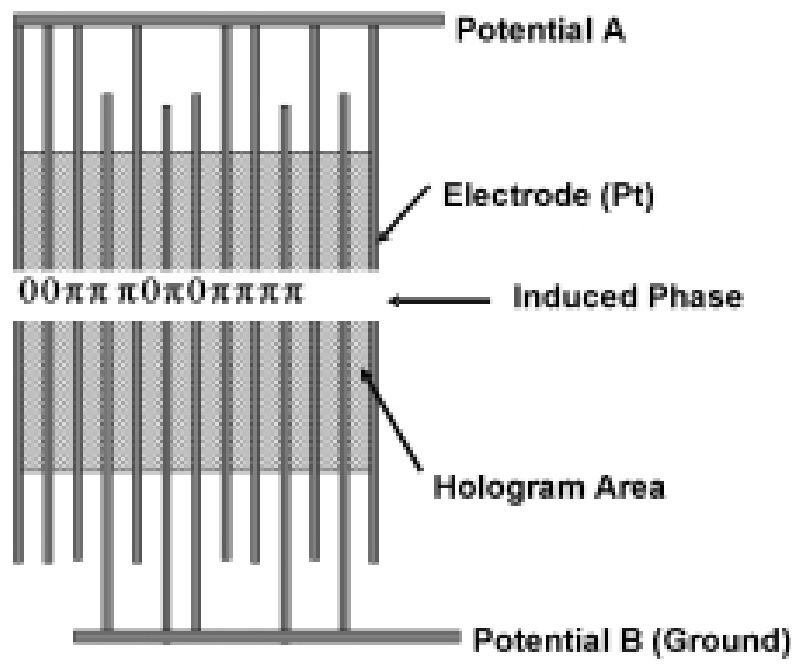

Fig. 6 Structure of electric filed modulated hologram.

り，A-Bの電位差が生じる空間で $\pi$ 位相を表現する。電界 変調ホログラフィーでは, ホログラム上に0と ムな配列が表現されるような電極配列が用いられてい る。再生像" $\phi "$ と" $\pi$ "はそれぞれ別々にホログラムを計算 し, " $\phi " の$ 画像はホログラム透過関数の正值のみから合成 $し$, " $\pi$ "の画像は正值と負值, 両方の透過関数值から構成

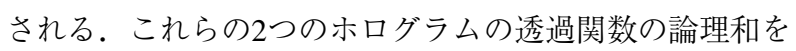
とってランダム位相配列ホログラムを構成した. Fig. 7に 電界印加による再生像の入れ替えを示す。電位がかかっ ていない状態では, " $\phi "$ は正常な像として再生されるが, " $\pi$ "は像は再生されない. なぜなら" $\pi$ "は負の振幅が誘起さ れたときのみ，スクリーン上での実確率が得られるが, 負の振幅として通過すべき穴から正の振幅で通過した波 は再生像を消去してしまう。一方で, 電界を与え, 位相

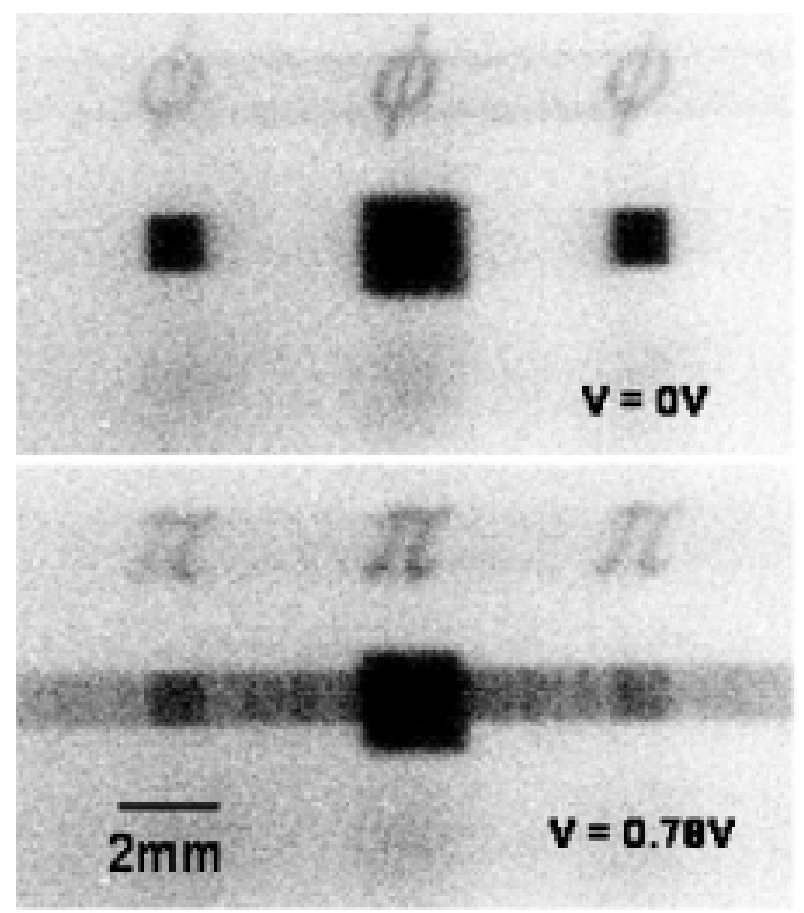

Fig. 7 Pattern changing by electric field. 
シフト $\pi$ 誘起されると事態は逆転し，" $\pi$ "像が正しく再生 される，正確に記述すると，それぞれ，電位なしの時 は，" $\pi$ "画像は $x$ 方向(電極の配列方向)に広がった背景ノイ ズになり，電界が与えられれ位相が誘起されたときには， " $\phi$ "画像がノイズとなっている，また，電極配列によって 1次元 $(x)$ 方向にのみランダムな位相シフトが誘起されるこ とから，正しくゼロと $\pi$ 位相とが誘起されたときには，ゼ ロ次光は $x$ 方向に拡散されたノイズとなる。またこのと き，再生像は正しい位相を持った原子波により，正しい 場所に形成される。

\section{5 冷却 $\mathrm{Ne}$ 原子の巨大量子反射と量子反射ホログラ フィー}

冷却原子の波動性を利用して原子波ホログラフィーが 実現した。透過型原子波ホログラフィーでは原子は薄い メンブレンホログラムを透過し, 干渉して原子再生像が つくられた。波であるから干渉性を保ったまま反射が起 きても良いはずである(つまり散乱ではない)，波の反射は ポテンシャルの段差で起こる. 光であれば屈折率の段差 のある界面，電気信号であればインピーダンスミスマッ チのある箇所，原子波ではポテンシャルの段差が相当す る。この段差を形成するポテンシャルは引力であっても 斥力であっても良い. 表面のvan der Waals ポテンシャル は, 冷却原子の速度に対して十分に急峻である. 真空中 において, 平面(反射面) と進入する原子との間のvan der Waals ポテンシャルは, $U=-C_{3} / r^{3}$ の形になり, 比較的近 距離で働くポテンシャルである.

このような反射表面からのポテンシャルに原子が低速 で入射すると原子の量子反射が起こる。この反射位置と 反射率を見積もるために, つぎのような簡単なモデルで 量子反射を考えてみる。まず，入射原子を平面波と考 え, 無限遠での原子の波数べクトルの大きさを $k_{0}$ とする と, ポテンシャル原点からrだけ離れたところでの原子の 波数 $\boldsymbol{k}$ は $k=\sqrt{k_{0}^{2}-2 m U / \hbar^{2}}$ となる. 一般に波は, 波長程度 進む間の波数の変化量 (これはポテンシャルの変化量に対 応) が元々の波数を越えるようなところで強く反射され る.すなわち, $\frac{1}{k} \frac{d k}{d r}>k$ がみたされるようなところで強 く反射される、今ここで， $\phi=\frac{1}{k^{2}}\left(\frac{d k}{d r}\right)$ を定義し，これを ポテンシャルの急峻さを表す指標とする，ポテンシャル を $U(r)=-C_{n} / r^{n}$ の形であるとして $\phi$ を計算すると $\left(C_{\mathrm{n}}\right.$ は係 数), $n>2$ の時に反射面からの距離

$$
z_{\max }=\left\{\frac{(n-2)}{(n+1)} \frac{m C_{n}}{\hbar^{2} k_{0}^{2}}\right\}^{1 / n}
$$

で $\phi$ は最大值をとる.

$$
\phi_{\max }=\frac{1}{z_{\max } k_{0}} \frac{n(n+1)(n-2)^{1 / 2}}{(3 n)^{3 / 2}}
$$

つまり反射面から有限の距離 $z_{\text {max }}$ で㠶極大值をとる. ここで $k_{0}$ がゼロに近づくとき，すなわち原子の入射速度 $v=\hbar k_{0} / m$ がゼロに近づくと, 波数べクトルの变化率 $\phi$ が
のになり反射率は 1 に近づく。つまり入射速度が遅くなる と反射率が高くなる。ここでポテンシャルの定数 $C_{n}$ は固 体表面の原子密度に比例した係数であるから, 表面原子 密度を下げると反射率が増大すると期待される。原子波 が反射を起こすのは波数べクトルの変化率 $\phi$ 最大になる ところであり，その距離 $z_{\max }$ はポテンシャル係数 $C_{n}$ が小さ いほど近くなる。つまり表面原子密度が小さいほど原子 は表面近傍まできて反射する。このときポテンシャルは 距離が近いほど急激に変化するから $\phi$ の最大值も大きくな り反射率も大きくなる.

筆者らはSi基板表面を加工し, 基板表面での見かけ上の 表面原子密度を変化させた時に反射率がどう変わるかを 実験的に調べた。 Ne原子を用いた反射率測定の実験系を Fig. 8に示す. 用いた Ne原子波源は従来の透過型ホログラ フィー用レーザー冷却装置と同様である。原子トラップ から解放され自由落下した原子はビーム絞りを通って $\mathrm{Si}$ 基 板に当たる. Si基板の大きさは幅 $20 \mathrm{~mm}$ で長さ約 $100 \mathrm{~mm}$ である．この基板は $1 \sim 40 \mathrm{mRad}$ の範囲で任意の傾斜角度 を持つように調整可能である。この極端に浅い傾斜角度 は水平方向から入射する $\mathrm{He}$ - Neレーザーで検出する，基板 面で反射した原子は自由落下原子とは離れた位置で反射 スポットとして観測され，この反射位置と強度を測定し て反射率特性が得られる。

原子波の反射率測定に用いた $\mathrm{Si}$ 基板の断面図をFig. 9に 示す.この回折格子状構造はSi基板の異方性エッチングを 用いて形成したものであり, 頂上の反射面は極めて平坦 である，原子の入射角度が非常に浅いので，格子の基本 間隔と各格子頂上に形成された反射面の幅を変えること で入射原子の感じる表面原子密度を変えることができ

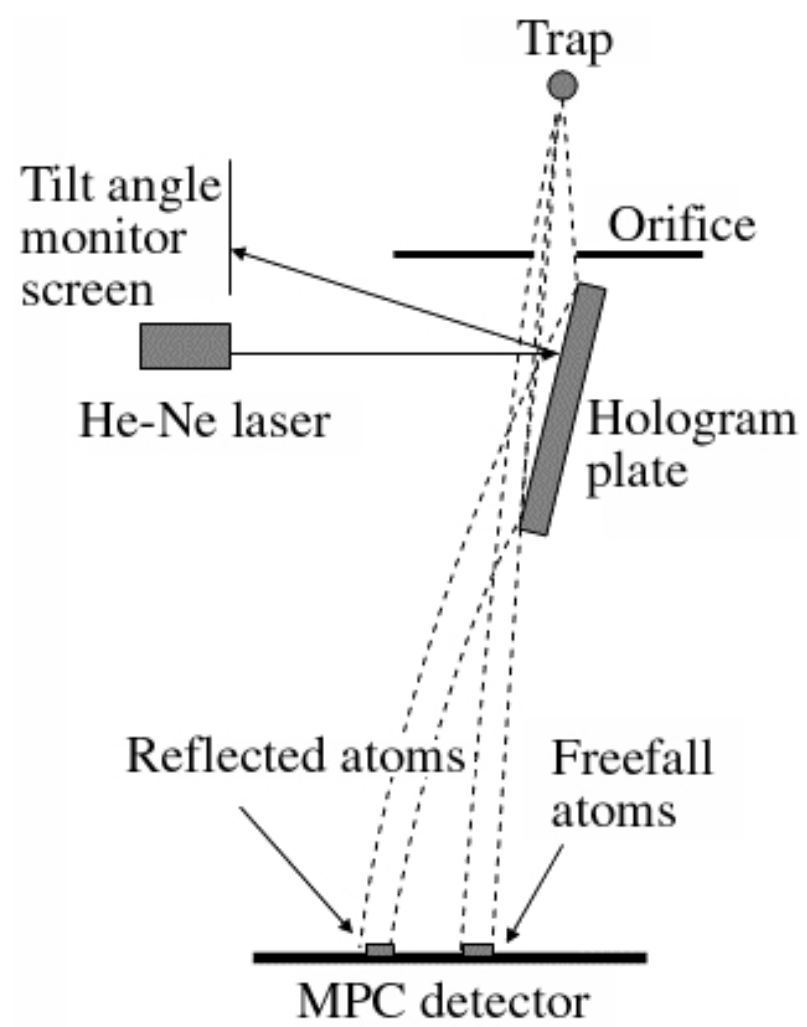

Fig. 8 Optics for measuring quantum reflection of atom. 


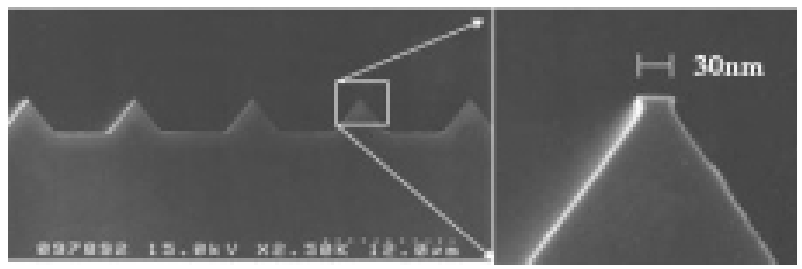

Fig. 9 Cross-sectional SEM image of blazed grating with top narrow ridge.

る. (5)式の実効的な值はせいぜい $0.1 \mu \mathrm{m}$ 程度であるか ら，この深さ範囲にある $\mathrm{Si}$ 基板の構造が入射する原子の感 じる表面原子密度に寄与する。 また，頂上の反射面の平 坦性が量子反射にとって重要である。頂上部に凹凸があ ると量子反射は起きない.

Fig. 10に反射率測定の結果に示す. 実線は平坦な $\mathrm{Si}$ 基板 表面での原子の量子反射の特性を示したものである。こ れに対して, 頂上に平坦かつ非常に幅の狭い反射面を形 成した格子では反射率が向上する，格子のピッチが 100 $\mu \mathrm{m}$ で幅 $11 \mu \mathrm{m}$ の反射面の場合(吕)平坦な $\mathrm{Si}$ 基板に対して3

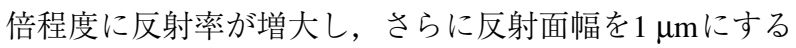
と( $\square$ )さらに約3倍増える。格子のピッチが $30 \mu \mathrm{m} て ゙ 0.1 \mu \mathrm{m}$ 幅の反射面 (O)ではさらに増大し，平坦な $\mathrm{Si}$ 基板表面の反 射率に対して約50倍以上の反射率が得られていることが わかる10).

この原子の巨大量子反射を利用して反射ホログラ フィーを行う事が可能である ${ }^{11)}$ 。反射型のホログラ フィーでは原子軌跡(光路)に対してホログラム面がほぼ並 行であるからホログラム計算にフーリエ変換は利用でき ない．ここでは，波源から射出された原子が重力加速の もとホログラム面に到達するまでの古典的軌跡に沿った 位相の進み $\phi_{1}$,

$$
\phi_{1}=\frac{m}{\hbar} \int_{\text {source }}^{\text {Hologram }} v^{2} d t
$$

とホログラム面で反射し，スクリーンに到達するまでの 軌跡に沿った位相の進み $\phi_{2}$,

$$
\phi_{2}=\frac{m}{\hbar} \int_{\text {hologram }}^{M C P} v^{2} d t
$$

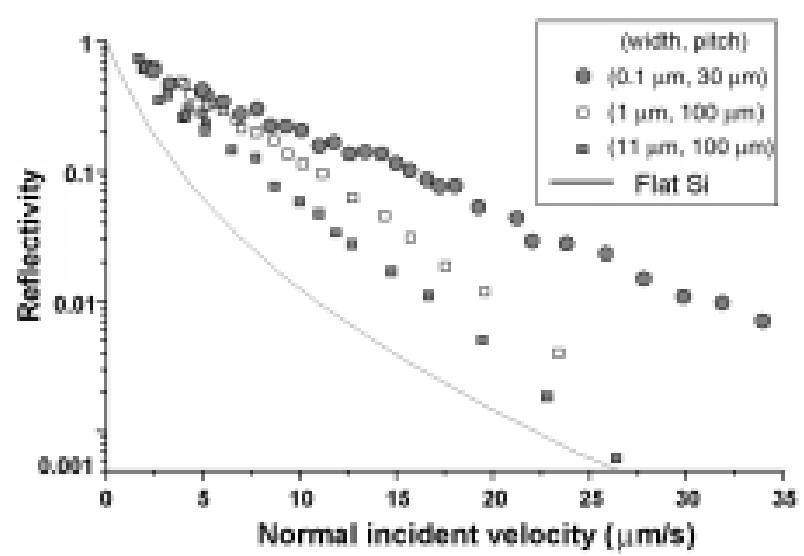

Fig. 10 Reflectivity of $\mathrm{Ne}$ atom on flat $\mathrm{Si}$ and blazed gratings.
を計算し，ホログラム面のピクセル構成を計算してい る。決定されたホログラムは，先に紹介した量子反射を 最大限に利用する。すなわち反射ピクセルを回折格子状 構造で構成し，実効的な反射強度を稼いでいる．Fig. 11に 実際に試作した反射ホログラム一部の写真を示す１つの ピクセルの幅が $25 \mu \mathrm{m}$, 長さが $100 \mu \mathrm{m}$ であり，これを 10 本 の格子で表現している。このホログラムの実際の寸法は 長さ $10 \mathrm{~cm}$ ，幅 $5 \mathrm{~mm}$ 程度である。また，波源とホログラム の距離が $44 \mathrm{~cm}$ ，ホログラムから $\mathrm{MCP}$ ホでが $68 \mathrm{~cm}$ であ る.ここに入射角にして $2.5 \mathrm{mRad}$ 程度の角度で原子を反射 させMCPスクリーン上に再生像を結像させた結果がFig. 12 である。シミュレーションでの像と良く対応して明瞭な 再生像が得られている。この再生像は約4時間の間に7万 個の原子を積算する事で構成されている。文字"SUR$F A C E "$ の直下に現れているゼロ次反射光を含めた原子総数 が約 150 万個であるから，4\%の反射原子効率で再生像が 構成されている。

\section{5. むすび}

透過型と反射型の原子波ホログラフィーが実際に動い たことで，原子波工学の必須部品である光学素子ができ た事になる。ホログラフィーでは，ホログラムを構成す

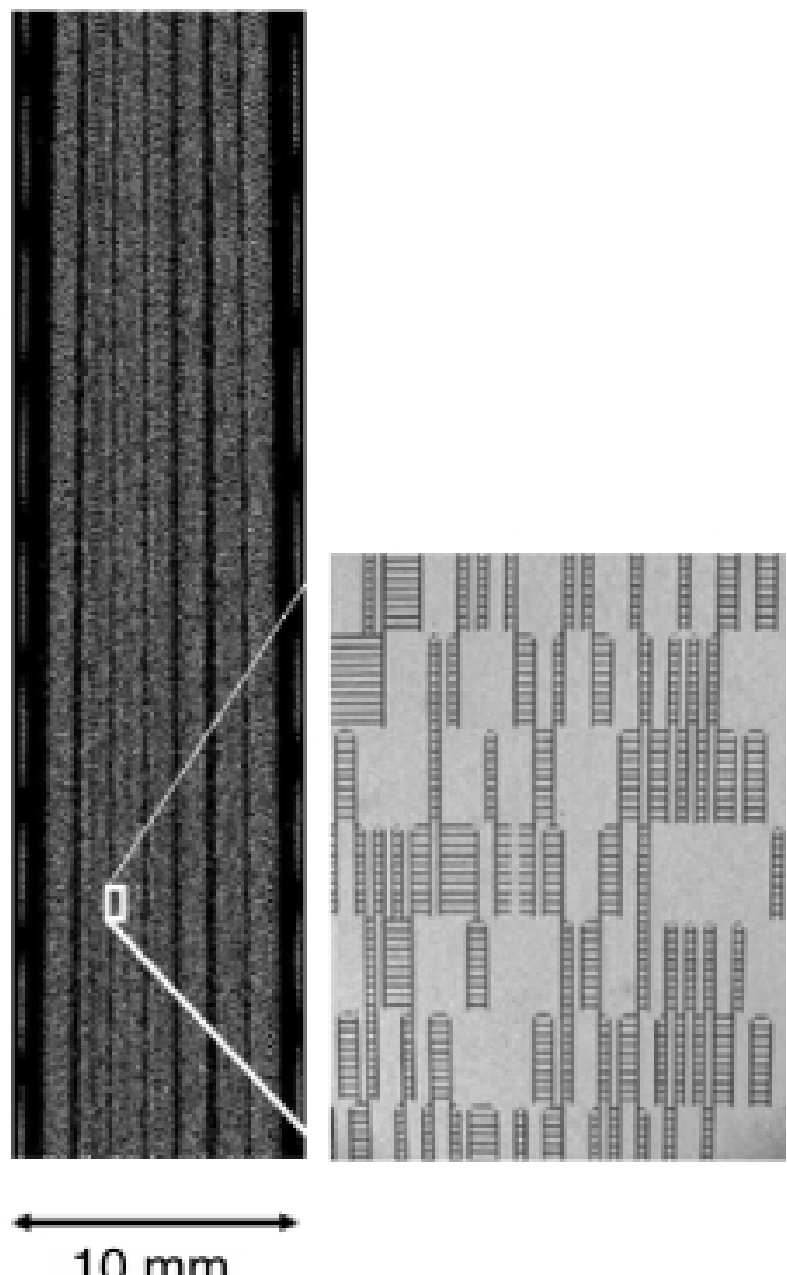

Fig. 11 SEM surface image of reflecting hologram. 


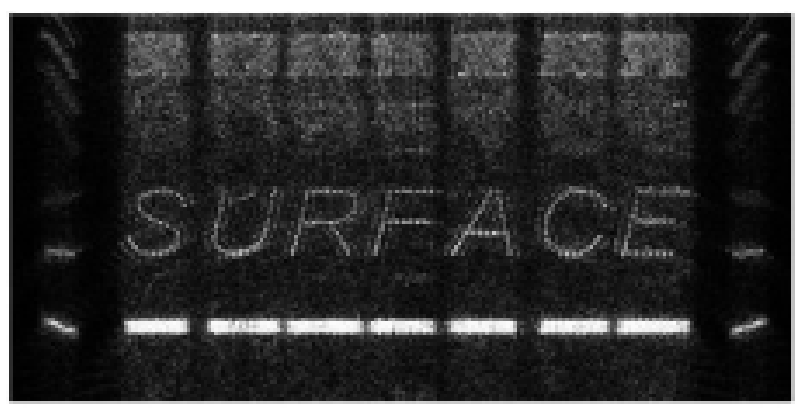

simulation

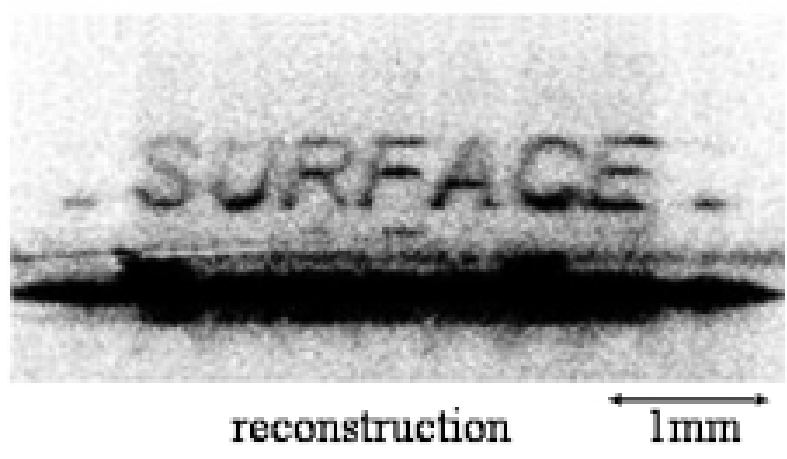

Fig. 12 Simulation and reconstruction of reflecting atom holography.

るセルの大きさが分解能の限界であり, この点で電子線 リソグラフィの加工限界值約 $10 \mathrm{~nm}$ が原子波ホログラ フィーの分解能限界となる。 しかし, 静電レンズ12) など の実レンズとの組み合わせで縮小原子光学系を構成すれ ば，原理的にはド・ブロイ波長程度のパターン形成も可 能である．また原子の巨大量子反射10) が見いだされ，反 射型ホログラムによる再生 ${ }^{11 ）}$ も実現している。これらの 原子波操作技術は微細パターンの直接形成など, 次世代
の新しいリソグラフイ技術であるとともに，超高精度干 渉実験など物理的にも大変興味深く応用範囲も広い. 純 粋物理のレーザー冷却に端を発し，原子波ホログラ フィーによって実用技術となりつつある原子波光学技術 が，今後より大きく発展していくことを期待したい.

\section{謝 辞}

本解説で紹介した原子波ホログラフィー技術は電気通 信大学・レーザー新技術研究センターの清水 富士夫先 生, 森永 実先生, 岸本 哲夫博士らとの共同研究による成 果であり, 関連各位に厚く感謝いたします。また, 本研 究はCREST-JSTの助成を受けて実施されたものです.

\section{参考文献}

1）清水 富士夫：応用物理学会誌 60 (1991) 864.

2) Appl. Phys. B, "Special Issue for Optics and Interferometry with atoms" B54 (1992) 319.

3) P. L. Gould, G. A. Ruff, and D. E. Pritchard: Phys. Rev. Lett. 56 (1986) 827.

4) K. S. Johnson, J. H. Thywissen, N. H. Dekker, K. K. Berggren, A. P. Chu, R. Younkin, and M. Prentiss: Science 280 (1998) 1583.

5) A. W. Lohmann and D. P. Paris: Appl. Opt. 5 (1967) 1739.

6) J. Fujita, M. Morinaga, T. Kishomoto, M. Yasuda, S. Matsui, and F. Shimizu: Nature 380 (1996) 691.

7) M. Morinaga, M. Yasuda, T. Kishomoto, F. Shimizu, J. Fujita, and S. Matsui: Phys. Rev. Lett. 777 (1996) 802.

8) T. Kishimoto, J. Fujita, S. Mitake, and F. Shimizu: Jpn. J. Appl. Phys. Lett. 38 (1999) L683.

9) J. Fujita, S. Mitake, and F. Shimizu: Phys. Rev. Lett. 84 (2000) 4027.

10) F. Shimizu and J. Fujita: J. Phys. Soc. Jpn. 71 (2002) 5.

11) F. Shimizu and J. Fujita: Phys. Rev. Lett. 88 (2002) 123201.

12) H. R. Noh, K. Shimizu, and F. Shimizu: Phys. Rev. A. 61 (2000) 041601.

\section{レーザーワード}

原子波ホログラフィー (atomic wave holography)

原子のド・ブロイ波を用いたホログラフィー．物質は 本来粒子の性質と波の性質とを合わせもっているが,

ド・ブロイ波は室温ではピコメートル程度と極めて短か い.しかし, レーザー冷却法を用いることで, 波長が数 ミクロンメートルにも達するド・ブロイ波を比較的容易
に得られ，光と同様の干渉による波面操作が可能であ る。原子を通す開口穴と，遮断する閉口穴の2值で構成さ れたバイナリーホログラムを用い，通過する原子波面を 制御し，ホログラムに記録された情報を再生することが できる。

(藤田 淳一) 